\title{
Gran Torino Clinta Eastwooda a smrt Západu
}

\author{
Lukáš Jirsa \\ Katedra teorie kultury (kulturologie) Filozofické fakulty Univerzity Karlovy v Praze, Celetná 20, 11000 Praha 1 \\ Do redakce doručeno 13. záŕí 2011; k publikaci přijato 7. listopadu 2011
}

\section{CLINT EASTWOOD'S GRAN TORINO AND THE DEATH OF THE WEST}

ABSTRACT This article is a thematic analysis of Gran Torino - a movie made by American actor and director Clint Eastwood. We interpret its story as a symbolic illustration of the end of one world's era. The main character Walt Kowalski is for us the incarnation of the Western civilization, which loses its dominant position in the world. But the Western values, the values of Christian civilization, are not forgotten. The essential on both, the material and ideological level, is transfered by Walt Kowalski to his disciple, young Hmong boy Thao.

KEY WORDS film analysis; sociological imagination; Western civilization; individual change; cultural shift

ABSTRAKT Článek se zabývá rozborem filmu amerického herce a režiséra Clinta Eastwooda Gran Torino. Děj tohoto filmu interpretujeme jako symbolické zobrazení konce jedné epochy světa. Hlavní hrdina Walt Kowalski zde představuje západní civilizaci, která ztrácí své dominantní postavení. Zároveň ale západní hodnoty, hodnoty křestanské civilizace, nejsou zapomenuty. To nejpodstatnější na rovině materiální i ideové Walt Kowalski předává svému svěřenci, hmongskému mladíkovi Thaovi.

KLÍČOVÁ SLOVA rozbor filmu; sociologická imaginace; západní civilizace; proměna jednotlivce; kulturní změna

\section{ÚVOD}

Závěr 19. století přinesl řadu událostí, které stály u mohutných proměn podmínek života člověka na planetě Zemi. ${ }^{1}$ S odstupem více než jednoho sta let můžeme s jistotou říci, že

1 Rád bych čtenáře upozornil, že obrat „obyvatel planety Země“ používám zcela záměrně. Chci tím zdůraznit rozměr našeho referenčního horizontu, který by pro všechny - všechny obyvatele planety Země - měl být sice tím nejzazším, ale zároveň zcela pochopitelným a obvyklým bodem, ke kterému se vztahujeme v realitě našeho každodenního života. Již desítky let totiž zcela jistě a prokazatelně žijeme v situaci, kdy život a jednání každého člověka na planetě Zemi ovlivňuje životy a možnosti jednání života všech ostatních lidí. Žijeme v době třetí socio-antropologické mutace (Jaroslav Krejčí), v době planetární éry (Edgar Morin), v době světověku (Radim Palouš), kdy jsme se již všichni dávno stali členy světové obce ohrožení (Ulrich Beck). Tuto skutečnost si bohužel povětšinou neuvědomujeme, čímž stále narůstá riziko částečného či úplného sebezničení lidstva. mezi ty nejvýraznější události patřil zrod automobilu $(1886)^{2}$ i filmového média (1895). ${ }^{3}$

Film a automobil se společně zrodily a společně také prošly velkým a nečekaným vývojem. Během více než jednoho století se z obou senzačních novinek sklonku 19. století staly zcela běžné fenomény, které neodmyslitelně patří k životu nejen většiny obyvatel Západu, ale pravděpodobně i většiny obyvatel planety Země. Člověk dnes stále ještě (zcela neuváženě) využívá pozitiva, která s sebou tyto změny přinesly, aniž by byl schopen dostatečně reflektovat jejich stránky

2 Za počátek vývoje dnešních automobilů můžeme pokládat rok 1886, kdy si Karl Benz v německém Mannheimu nechal patentovat svoji motorovou tř́kolku.

3 S trochou nadsázky můžeme říci, že se film narodil 28. prosince 1895. Toho dne se v pařížské kavárně Grand Café uskutečnilo první veřejné filmové představení. Promítalo se jedenáct krátkých filmů (každý v délce přibližně jedné minuty), jejichž autory byli bratři Lumièrové. 


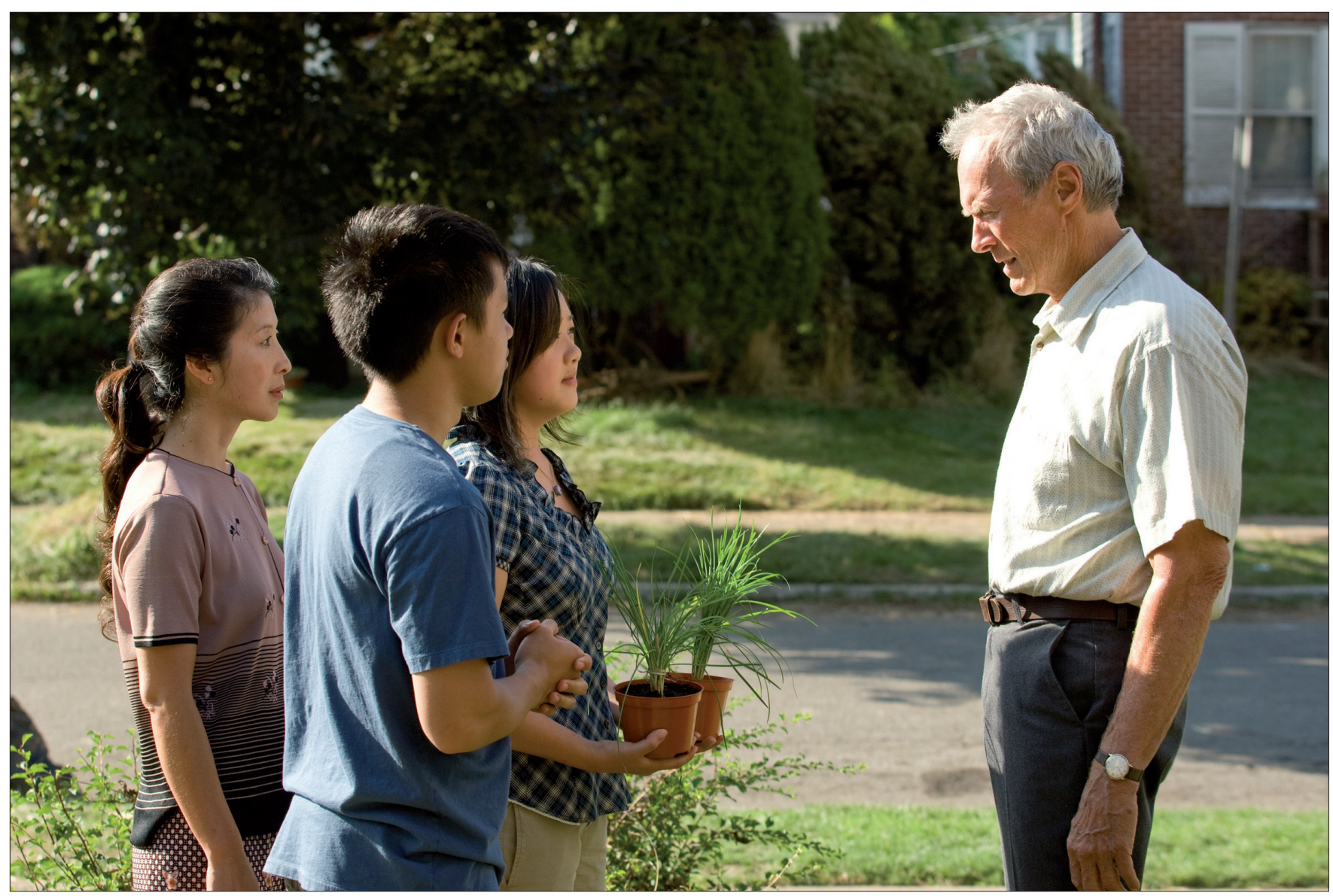

„... nekontrolovatelné přistěhovalectví hrozí zničit národ, v němž jsme vyrůstali, a proměnit Ameriku v konglomerát národů, které nemají téměř nic společného - ani dějiny, ani hrdiny, ani jazyk, ani kulturu, ani víru a ani předky“ (Buchanan 2004, 22).

stinné. Automobil se během let své existence stal kromě jiného jedním z ukazatelů společenského statusu. Nejen v severoamerické společnosti, ale rozhodně právě v ní, dotváří značka a model auta osobnost svého majitele.

$\mathrm{V}$ následujícím textu se zaměříme na celovečerní americký film Gran Torino režiséra a herce Clinta Eastwooda. Tento film již ve svém pojmenování nese název jednoho oblíbeného automobilového modelu značky Ford. Vůz v tomto realistickém dramatu nabývá stejných hodnot jako ve skutečné americké společnosti. Je takřka charakterovým doplňkem svého majitele a o svém majiteli tak mnohé vypovídá. Ačkoli je značka vozu v samotném názvu filmu, dané auto rozhodně není ve středu pozornosti vyprávění. Je spíše na periferii zájmu, zároveň je ale zásadním elementem, který nelze při promýšlení tohoto uměleckého díla pominout. Stejně tak tomu bude i v našem textu: Ačkoli se nebudeme přímo zabývat autem typu Gran Torino jako takovým a nebudeme jeho prizmatem interpretovat film (i když připouštíme, že by zajisté šlo o zajímavý esej), tento zvláštní artefakt bude vždy v pozadí naší interpretace. V závěru pak ukážeme, jak zásadní úlohu vůz Gran Torino v Eastwoodově filmu má a to nejen pro svého majitele, kovaného Američana Walta Kowalskiho.

\section{CLINT EASTWOOD A JEHO GRAN TORINO}

Snímek Gran Torino natočil slavný herec druhé poloviny 20. století, dnes již více než osmdesátiletý Clint Eastwood (narozen 1930). Tento nezdolný a neúnavně pracující muž má $\mathrm{v}$ americkém filmovém průmyslu pevnou pozici od poloviny 60 . let minulého století, kdy hrál v sérii úspěšných spaghetti westernů režiséra Sergia Leoneho. Od 70. let se Eastwood díky snímku režiséra Dona Siegela Drsný Harry (Dirty Harry, 1971) stává hereckou hvězdou první kategorie a zároveň také začíná samostatně režírovat. Eastwood mezi lety 1971 a 2011 režíroval 32 celovečerních filmů a v současné době je jedním z nejstarších aktivních amerických režisérů. (Na rozdíl od Evropy jsou v USA případy režisérů-starců daleko méně časté.) Zatímco jeho herecká kariéra byla zpočátku založena spíše na jeho vyzáblé postavě a drsné ošlehané tváři, jeho režijní opusy od samého začátku dávaly jasně najevo, že nejde jen o „režírujícího herce“, ale o plnohodnotného filmového tvůrce. Eastwoodovy režijní i herecké kvality s časem zrály, až nakonec dosáhl nejvyšších uznání v obou kategoriích (alespoň podle získaných filmových cen a nominací).

Gran Torino je dílem vyzrálého člověka, jenž je pevně svázán s kulturou Spojených států amerických. Eastwooda lze dokonce považovat za jednu z ikon americké kultury a spo- 


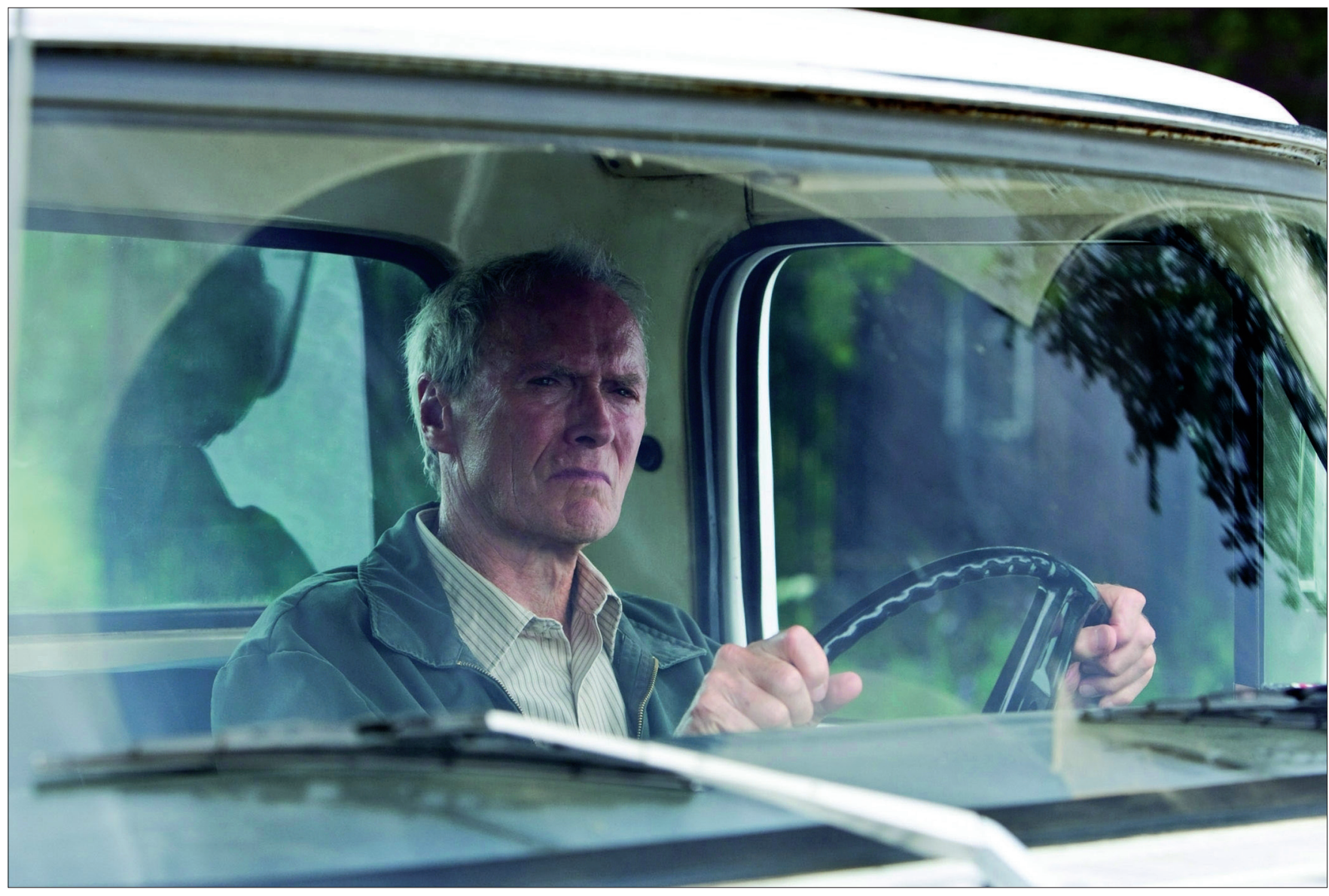

„Už světu nerozumí: svět, jemuž rozumí, už zde není. Není zproštěn nutnosti porozumět nesrozumitelnému ani osvobozen od pout minulosti. Není žádným hrdinou, je kýmkoliv a je právě tak statečný jako kdokoli, kdo stárne a zemře“ (Améry 2008, 137).

lečnosti, na jejímž formování se jako herec, režisér a aktivní americký občan sám podílel a dosud podílí.

V jistém smyslu je drama Gran Torino Eastwoodovou filmovou závětí. Jedná se totiž o jeho poslední velkou hereckou roli, jak on sám opakovaně prohlásil $\mathrm{v}$ rozhovorech $\mathrm{k}$ tomuto filmu. ${ }^{4}$ Gran Torino dosáhlo velkého diváckého i kritického ohlasu a stalo se dokonce Eastwoodovým komerčně nejúspěšnějším filmem vủbec. Vysoká návštěvnost Eastwoodova snímku je dána jasným, tradičně lineárně vyprávěným př́iběhem, jednoduchým (alespoň zdánlivě) charakterovým rozvržením hlavních postav a $\mathrm{v}$ neposlední řadě i suchým a ironickým humorem, který je $\mathrm{v}$ tomto tragickém př́iběhu často akcentován.

Gran Torino ovšem není jen divácky atraktivním snímkem. Je mimo jiné i svébytným dílem uměleckým a jako každé skutečné umělecké dílo také Gran Torino je dílem otevřeným. Je filmem zvoucím diváka $\mathrm{k}$ participaci, $\mathrm{k}$ dialogu, ke spočinutí a $\mathrm{k}$ promýšlení.

4 Skutečně zde můžeme hovořit pouze o závěti částečné, protože Clint Eastwood je i nadále činným režisérem. Od realizace Gran Torina stihl natočit již několik dalších snímků: Neporažený (Invictus, 2009), Život po životě (Hereafter, 2010), J. Edgar (J. Edgar, 2011).

\section{UMĚNÍ JAKO NÁSTROJ SOCIOLOGICKÉ IMAGINACE}

Před samotnou interpretací snímku je nutné osvětlit, jak vnímáme fenomén umění a konkrétněji filmu. Umění je pro nás neoddělitelně spjato $s$ každodenním životem. Používáme umění jakožto nástroj porozumění každodenní realitě, tedy jako vhodný prostředek sociologické imaginace (Jirsa 2010). ${ }^{5}$ Tímto jasně překračujeme čistě estetický př́stup k umění. Estetický př́stup je totiž překonán tehdy, když „bereme umèní vážně a rozpoznáváme $v$ něm jakousi řeč, jež běžným zpưsobem a bezprostředně nepojmenovává věci a situace, nýbrž vyjevuje podstatnou významovou a hodnotovou artikulaci světa" (Mokrejš $1995,21)$, která ve svém posunu od reality vyžaduje výklad, aby jí bylo porozuměno. Film je pro nás způsobem, jak „nověc

5 Sociologickou imaginaci, původně koncept amerického sociologa Charlese W. Millse, pojímáme jako prostředek lepší orientace jednotlivce ve světě. Podle Millse sociologická imaginace dovoluje „pochopit širši historickou scénu v jejím významu pro vnitřní život a pro vnější životní dráhu různých jednotlivcü“ (Mills 2002, 9). Zároveň vede $\mathrm{k}$ uvědomění si skutečnosti, že každý člověk „prostým faktem svého života přispivá, jakkoli nepatrně, $k$ vytváreni této společnosti a k průběhu jejích dějin" (Mills 2002, 10), přičemž je sám touto společností a jejími dějinným působením významně formován. 


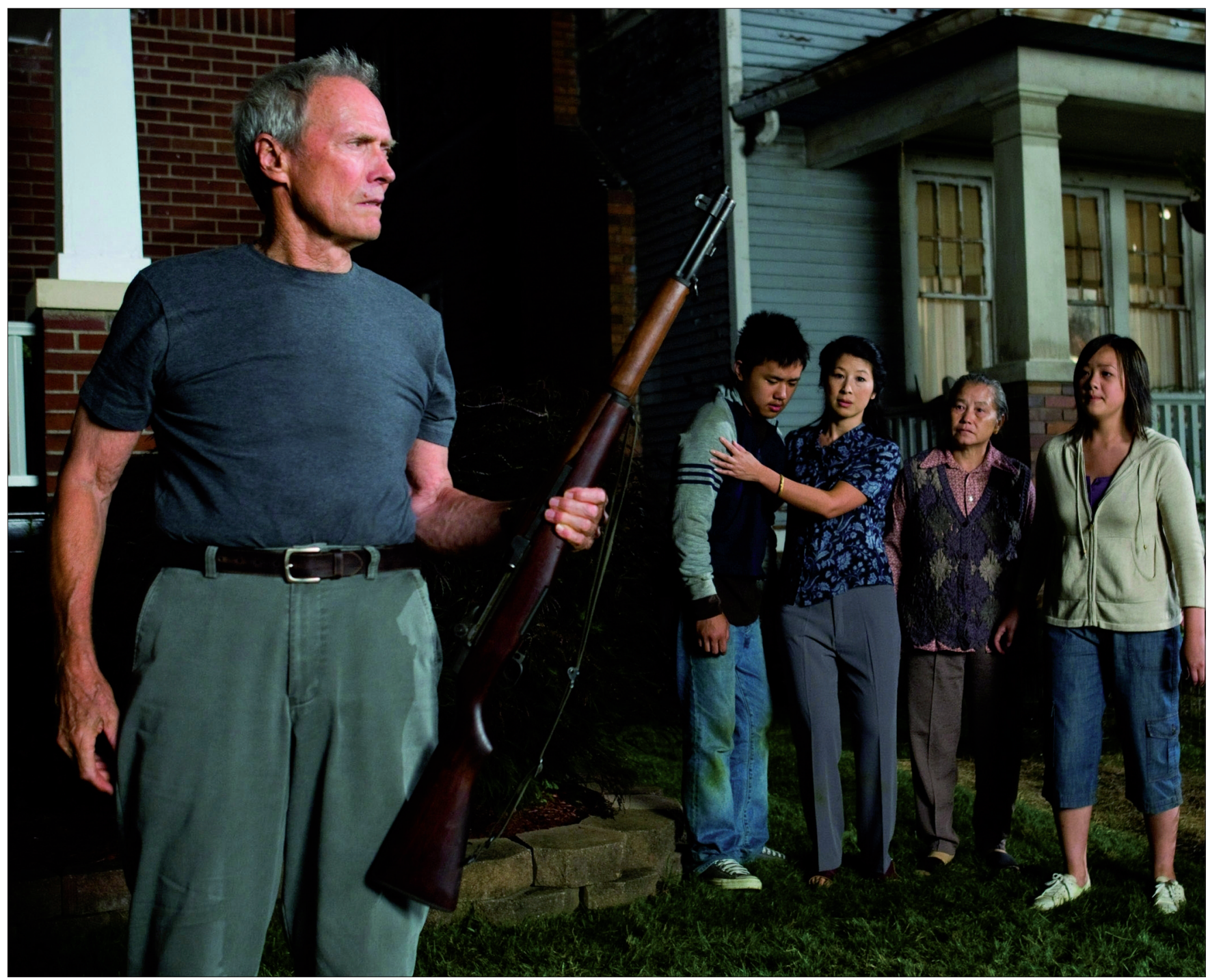

„Lidstvo stojí před dvojnásobnou výzvou: jak hledat cestu k pochopení nového světa s tolika dosud skrytými rysy a jak se v mlhovinách nejistoty naučit řídit tento nový svět - i jak se mu přizpůsobit“ (King - Schneider 1991, 16).

pohlížet na svět kolem nás, jak se znovu a jinak zamýšlet nad skutečnostmi i možnostmi našich životů. Film umožňuje nahlédnout nejen svět takový, jak jej známe, ale také svět možnosti a nepravděpodobnosti, svět vzdálený, svět neznámý či svět námi ještě neobjevený.

Jaký svět nám odhaluje film Gran Torino? Film, jehož název odkazuje k populárnímu americkému modelu auta? Film, jehož hlavní hrdina Walt Kowalski (Clint Eastwood) celý život bydlel na předměstí amerického Detroitu a celý život pracoval v továrně vyrábějící auta značky Ford?

Film Gran Torino uchopíme jakožto symbolický př́běh o konci západní civilizace (či alespoň určité její podoby), která postupně uvolňuje prostor civilizaci jiné. Př́běh Walta Kowalskiho a jeho auta je totiž teskným loučením s tradiční Amerikou fordovského střihu, je loučením s americkým snem, loučením s civilizací Západu. Ve filmu Gran Torino západní civilizace předává své žezlo dál a nám nezbývá než doufat, že i ve skutečnosti bude následující vưdčí civilizací prèevzato to nejlepší, co křestanský západ světu dokázal nabídnout. (Samozřejmě v př́ípadě, že se obyvatelé Západu včas nevzpamatují ze své blahobytné slepoty, čímž by se otevřela alespoň teoretická možnost zvrátit již dlouho běžící rozkladný proces západní společnosti.)

\section{STA ŘEC NA ODSTŘEL}

Film Gran Torino otevírá scéna pohřbu v katolickém kostele kdesi na předměstí amerického Detroitu. Ocitáme se v jednom ze symbolů amerického průmyslu. Jsme ovšem na začátku 21. století a město má svoji největší slávu již za sebou. Walt Kowalski, vyzáblý vysoký muž s ostře řezanými rysy, pichlavýma očima a chraplavým hlasem, přijímá kondolence a ostř́žím zrakem sleduje přicházející členy své rodiny. S despektem hledí na své dva dospělé syny a s viditelným odporem pak sleduje svá nezvedená pubertální vnoučata. Jeden chlapec ledabyle pokleká a neuměle se pokouší pokřižovat, 


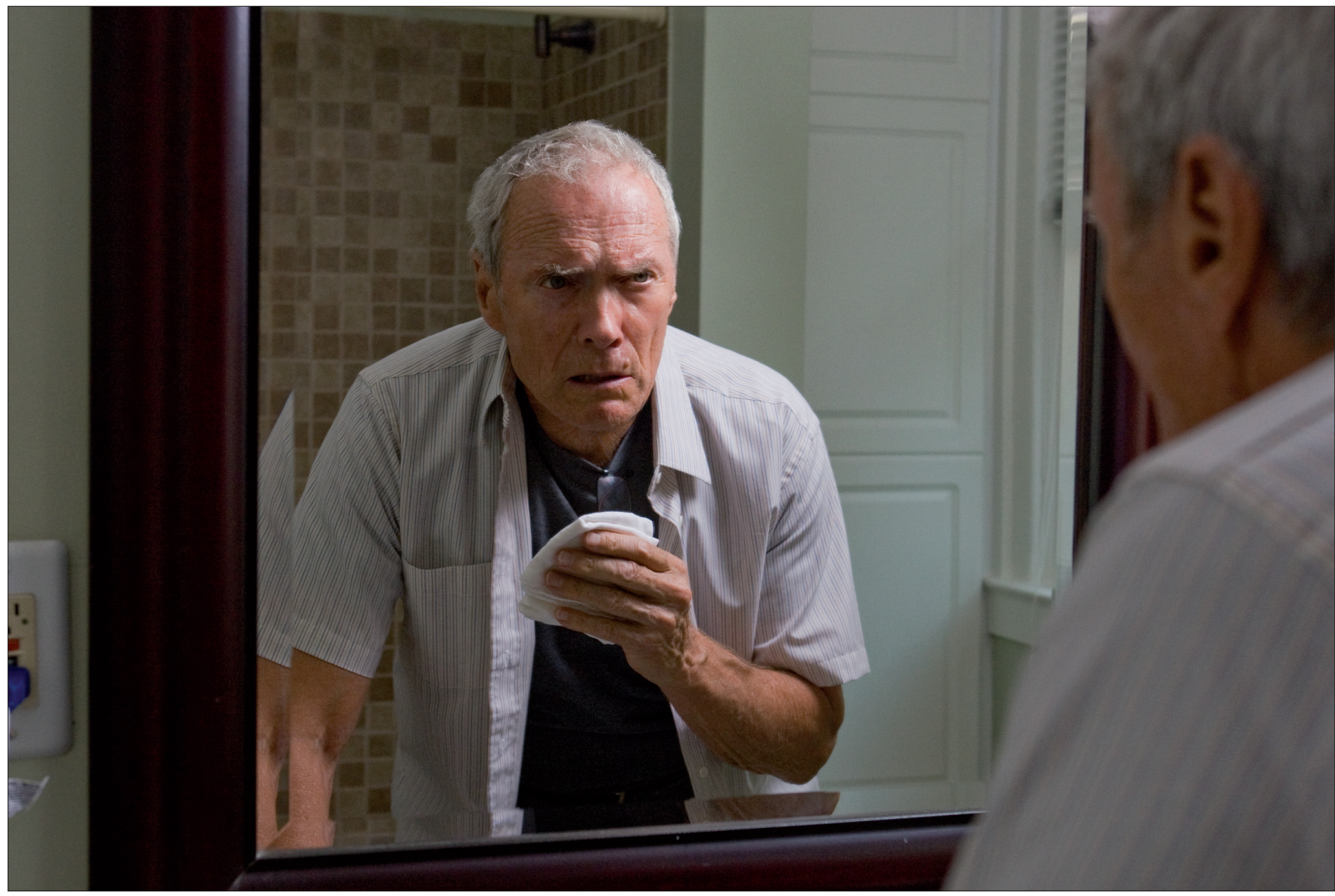

„Je úpadkový takový život, kterému uniká sám vnitřní nerv jeho fungování, který je porušen ve svém nejvlastněǰšm jádře, takže domnívaje se, že je plným životem, ve skutečnosti se každým svým krokem a činem vyprazdňuje a mrzačí. Je úpadková společnost, která svým fungováním vede k úpadkovému životu, v životu v propadlosti tomu, co není povahou bytí lidského“ (Patočka 1990, 107).

další zvládne křižování bez váhání, ovšem s otevřeně blasfemickou průpovídkou, vnučka Ashley se pak ani neobtěžovala zvolit vhodné oblečení a na pohřeb své babičky se dostavila v bledě modrém tričku nechávajíc na odiv své břicho i teprve rozvíjející se poprsí. Walt Kowalski, zdá se, opovrhuje takřka všemi: svými rodinnými př́slušníky i mladým knězem, který odříkává patetické věty o „hořkosladké smrti, která bolí zármutkem a pak sládne ve spasení.

Walt Kowalski je muž, který ustrnul v minulosti a který během filmu projde radikální zkušeností, jež ho zcela promění. Walt Kowalski je muž žijící ve světě, který již není. Patří minulosti, stejně jako patř́i minulosti jeho milované auto Gran Torino, jež vlastní od roku 1972. Jakožto zaměstnanec automobilky Ford, kde pracoval celých 50 let, do něj vlastnoručně montoval součástky a od roku 1972 se o ně vzorně staral. Po smrti manželky je pak nablýskaný vưz jednou z mála věcí, které mu v jeho opuštěném bytí dělají radost. A je také jednou z mála jistot, které ještě Waltovi zbyly. Kromě auta mu klid a jistotu přináší ještě věrný pes Daisy, několik dobře vychlazených piv, vždy nabitá puška, svědomitě udržovaný trávník a také americká vlajka, která hrdě zdobí jeho rodinný dům. Walt je jedním z posledních obyvatel čtvrti, která se během let stala bydlištěm asijských přistěhovalců, příslušníků komunity asijských Hmongů. Walt Kowalski k nim chová jasný despekt a nešetří otevřeně rasistickými výroky na jejich adresu: „Kolik žlutejch myší se nacpe do cimry?“ mumlá si pro sebe při pohledu na sousední dům, do kterého právě přicházejí př́íslušníci místní asijské komunity, a svá nevraživá slova zakončí opovržlivým odplivnutím.

\section{WALT KOWALSKI JAKO PERSONIFIKACE ZÁPADU}

Interpretace děje Gran Torina jakožto symbolického zobrazení konce jedné epochy světa, epochy, které vévodily ideje západní křest’anské civilizace, a zároveň začátku epochy nové, začíná - jak jinak - již během úvodních scén filmu. Zatímco starý a těžce nemocný „obyvatel Západu“ Walt Kowalski asistuje na pohřbu své milované ženy a sleduje ztrátu kulturní kontinuity ve své vlastní rodině (Walt je odcizen jak svým synům tak vnoučatům), ve vedlejším domě obývaným hmongskou rodinou právě probíhá oslava narození dítěte doprovázená patřičným náboženským obřadem.

Walt Kowalski ve filmu zosobňuje ještě tradiční Ameriku, Ameriku plně fordistickou, již ale není schopen vnímat důležitost svých křestanských tradic a je tedy, aniž by si toho 


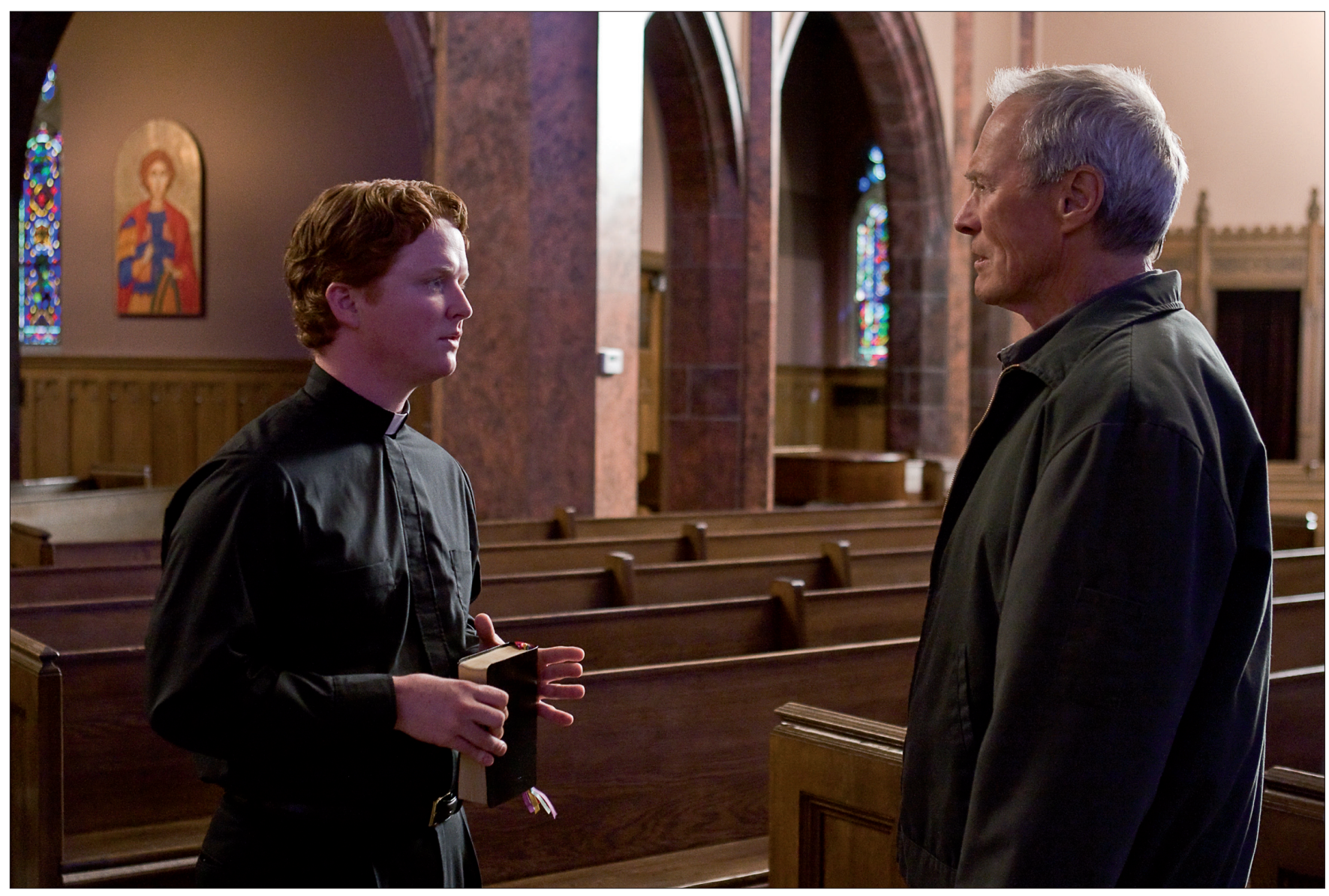

„Vazba společnosti a náboženství není nikterak nahodilá. Je velice naivní vysvětlovat ji souhrou historických okolností, náhod a rozhodnutí. Náboženství a společnost tvoř́ jednotu. Bez náboženství je společnost předem odsouzena ..." (Bauman 2002, 122).

byl vědom, sám značně postižen kulturní diskontinuitou. Walt Kowalski je člověkem, jehož život se ocitá na rozhraní dvou různých světů. Byl vychován během 30. a 40 let 20. století v pevném řádu, který se ale během života postupně stále více rozkládal a proměňoval. Kowalski je reprezentantem poslední generace, která ještě svůj aktivní život začínala v době, kterou sociolog Zygmunt Bauman nazývá „pevnou modernou“. To je podle něj čas, kdy „každý, kdo jako mladý učeň začal pracovat u Forda, si mohl být téměř jist, že na stejném místě svůj pracovní život také ukončí. Časové horizonty $\mathrm{v}$ éře ,pevné moderny byly dlouhodobé. Horizont dělníků určovala vyhlídka na celoživotní zaměstnání $\mathrm{v}$ rámci firmy, která snad nebyla nesmrtelná, ale délka jejího života rozhodně přesahovala průměrnou délku života jejích zaměstnancü“ (Bauman 2004, 32). Paradox života Walta Kowalskiho spočívá v akceleraci vývoje západní společnosti, která vrcholí ve druhé polovině 20. století a na začátku století následujícího: Kowalski vyrostl v končící době fordistické (30. a 40. léta 20. století), během 50. let vstoupil do „společnosti pozdní doby“ (Petrusek 2007), v rámci které se již v roce 1972, kdy si pořídil své pečlivě opečovávané Gran Torino, ocitl ve „společnosti postfordistické“ (Petrusek 2007, 33), na jejímž samém konci (začátek 21. století) se odehrává celý děj filmu. Připomeňme, že společnost pozdní doby doyen české sociologie Miloslav Petrusek popisuje také jako společnost, „kterou lze metaforicky přirovnat $\mathrm{k}$ sopce, o níž nejen nevíme, zda je činná či nikoliv, ale už vưbec ne, zda a kdy může vybuchnout a s jakými následky“ (Petrusek 2007, 25). Walt Kowalski je symbolickou personifikací moderního světového systému (západní civilizace), jenž „Vstoupil do stadia konečné krize a je nepravděpodobné, že by mohl existovat ještě půl století' (Wallerstein 1999, 1). Walt Kowalski sám je vlastně chodící dřímající sopkou, která se chystá vybuchnout, a divák je v lačném očekávání jejího výbuchu stále systematicky podporován a na její skutečně mohutný výbuch připravován.

$\mathrm{V}$ rámci interpretace postavy Walta Kowalskiho jako personifikace západní civilizace na začátku 21. století pak ve filmu dochází k zajímavému a vlastně naděje plnému vývoji. Kowalski totiž postupně překonává svůj arogantní a jasně odmítavý postoj ke svým hmongským sousedům, zadržuje a oddaluje svůj sopečný výbuch, a zjištuje, že s jejich pospolitou komunitou žijící v rámci dlouhodobě udržovaného řádu, má více společného, než se svými vlastními dětmi. (A ještě aby ne, když jeho synové již vyrůstali v 60. letech 20. století, kdy rozpad hodnot a řádu Západu již probíhal na plné obrátky, a jeho vnučka Ashley se svými sourozenci i bratranci se narodila do světa, ve kterém již neexistují 


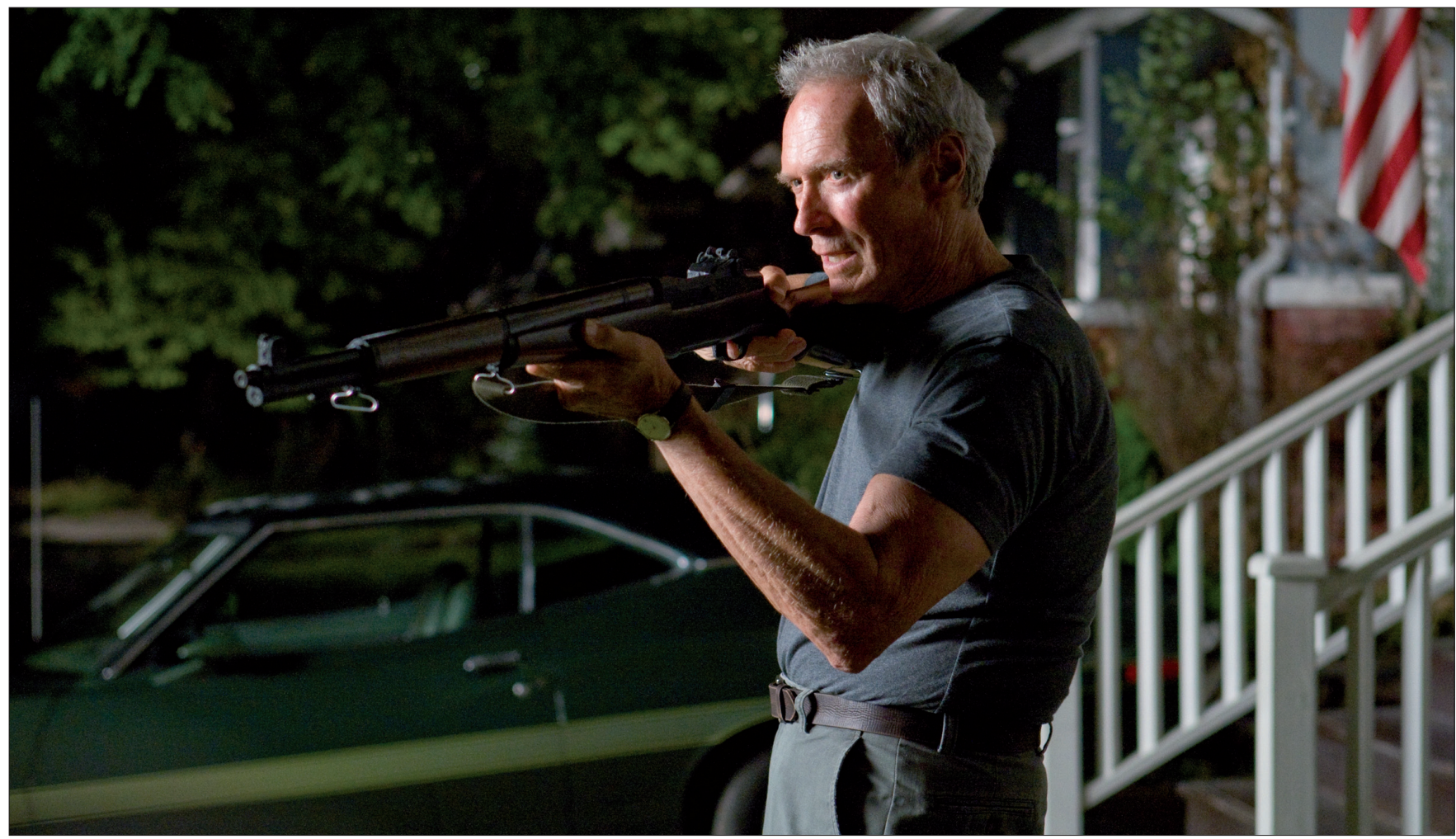

„V rizikové společnosti se vyrovnávání se strachem a nejistotou stává biograficky a politicky klíčovou civilizační kvalifikací a formování schopností, které jsou k tomu potřebné, základním úkolem pedagogických instituci' (Beck 2004, 101).

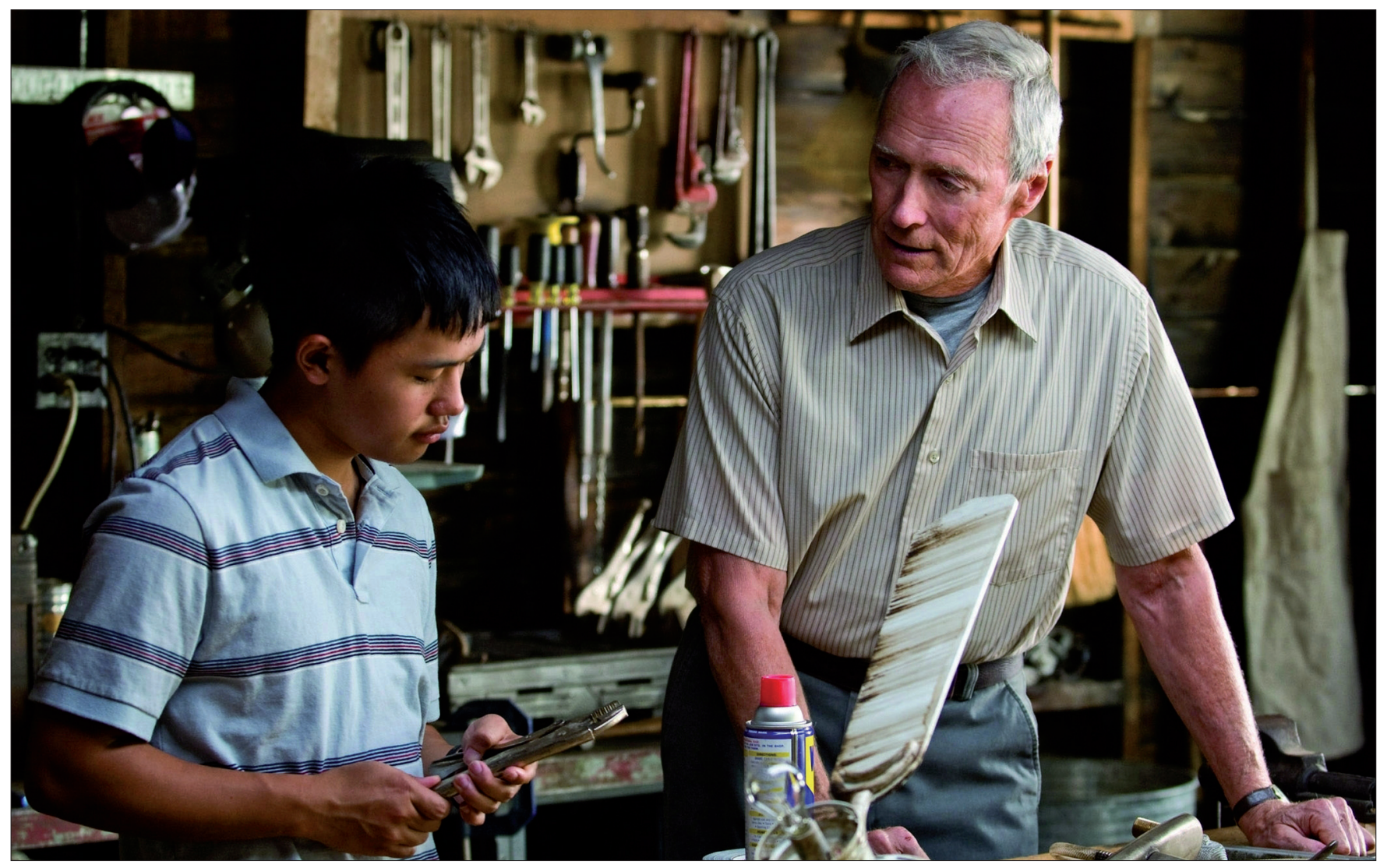

Výchova není jen praktickou přípravou k určitému povolání, „ale je vyváděním z každé částečnosti, z každé uzavřenosti ve sféře omezených zájmů do prostoru otevírajícího se jediným skutečně lidským směrem: od dílčího k celkovému“ (Palouš 1991, 161). 


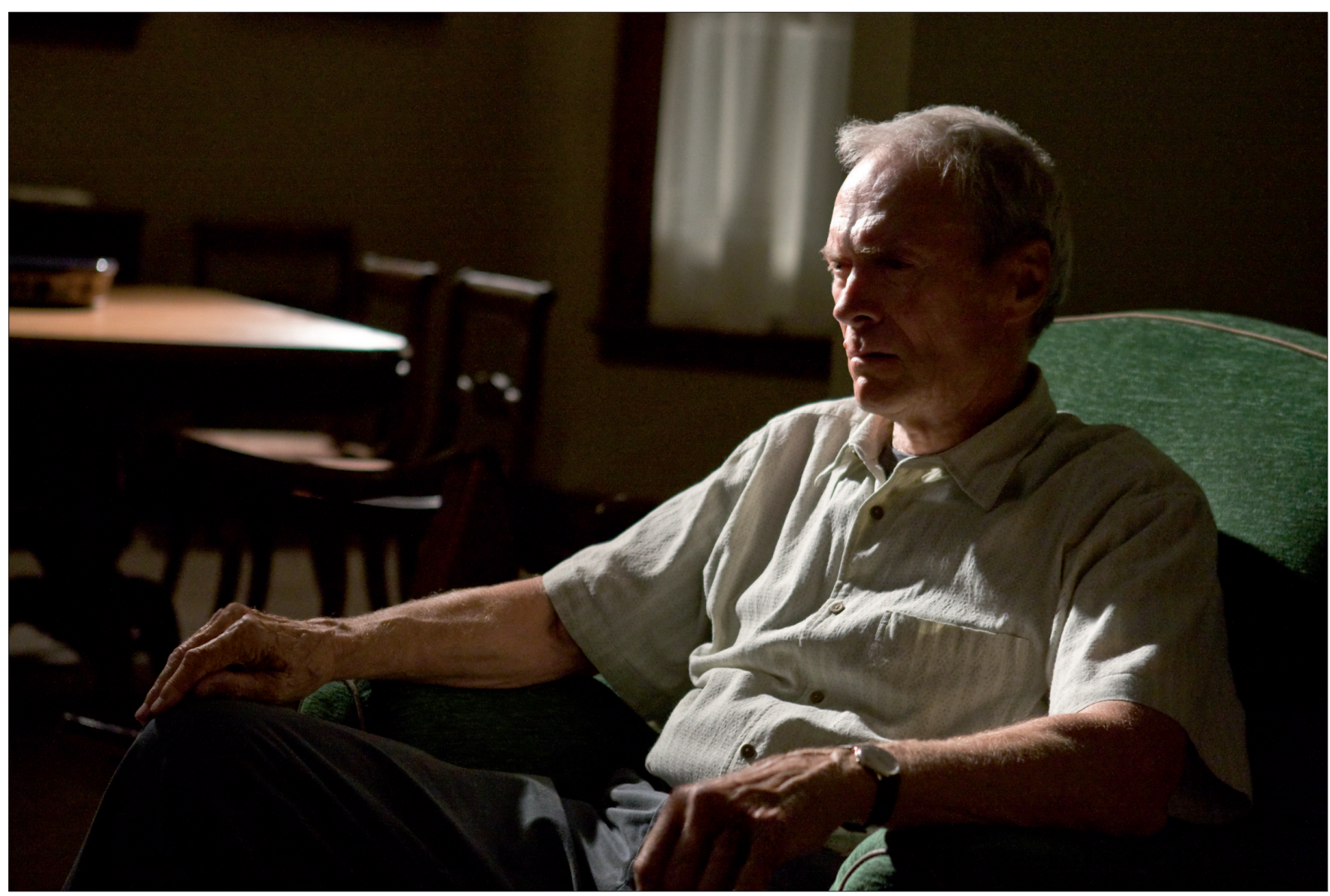

„Tím, k čemu se obrací filozofická úvaha, je stejný viditelný svět, který máme všichni před očima. Avšak tohoto světa, těchto věcí, těchto skutečností se dotazujeme zvláštním způsobem“ (Pieper 2007, 51-52).

žádné záchytné body, do světa plně individualizovaného, tekutého a ničím neohraničeného.) Kowalski díky pronikání do životních zvyklostí svých sousedů zjištuje, že obývají svět funkčních tradic, kde jsou mužské a ženské role ještě jasně rozděleny, kde mladí lidé mají úctu k lidem starším a kde panuje vědomí zakořeněnosti $\mathrm{v}$ určité kultuře. Tento svět Kowalski obýval a znal ve svém mládí, tento svět je mu známý a blízký - a paradoxně jej objevuje u nenáviděných „žlutých myší, jejichž mrtvoly za časů války v Koreji používal se svými spolubojovníky namísto pytlů s pískem jako ochranný val před protivníkem. Sám Kowalski poznáním vnitřní blízkosti s Hmongy není nijak nadšen a v den svých 80. narozenin, kdy se ocitá na jakémsi hmongském setkání $\mathrm{u}$ sousedů $\mathrm{v}$ domě, se značnou trpkostí v hlase konstatuje: „Já mám s tou bandou pošuků víc společnýho než s vlastní rodinou. Ježišíkriste! Všechno nejlepší," pronese poté, co jej místní šaman „přečetl“ (tj. naprosto přesně vystihl stav jeho vyhaslého nitra).

Starý a odcizený Walt se cítí blíže pospolitě žijícím Hmongům - a není divu. Vždyt i západní civilizace vyrostla na podobných principech. Ty ovšem $\mathrm{v}$ západním okruhu vyrůstaly $\mathrm{z}$ křestanské tradice a morálky. Principy pěstované křestanstvím nicméně byly během 20. století již definitivně opuštěny jakožto svazující, nesvobodné a znemožňující to- lik vítaný technický a vědecký pokrok lidstva. Walt sám sice také na vědomé úrovni nepřijímá katolickou církev (ve filmu reprezentovanou postavou mladého kněze), ale křestanské principy - tedy kořeny západní civilizace, jsou v něm ještě pevně zafixovány. Tyto principy se $\mathrm{v}$ průběhu děje, kdy se Walt stává ochráncem spořádané hmongské rodiny před místním hmongským gangem, stávají jádrem toho, co Walt předává mladému muži Thaovi. Walt učí dospívajícího chlapce mužnosti, píli, odpovědnosti za druhé, učí ho respektu vůči autoritám. Vrcholem jeho učení pak je poslední čin jeho dlouhého a vlastně tragického života, obětování sebe sama pro život druhých. Walt se od smrti své manželky (a pravděpodobně i předtím) projevoval značně misantropicky, k čemuž měl ovšem jasné důvody (jasné z hlediska poznatků psychologie, nikoli jasné z hlediska Walta samotného): svůj majetek bránil se zbraní v ruce, se syny nedokázal nikdy navázat skutečně blízký vztah (jeden z jeho synů se mu do telefonu představuje jako „syn číslo jedna, Mitch“), jeho postoje jsou otevřeně xenofobní a rasistické. A během korejské války v roce 1951 zabil bezbranného muže. Tento čin mu zabránil v klidném prožití dalšího života, protože si ho nikdy nedokázal odpustit. Kvůli svému dávnému hř́íchu z války toho Kowalski „ví víc o smrti než o životě“, jak konstatuje mladý kněz, jenž na Kowalskiho neustále doráží 


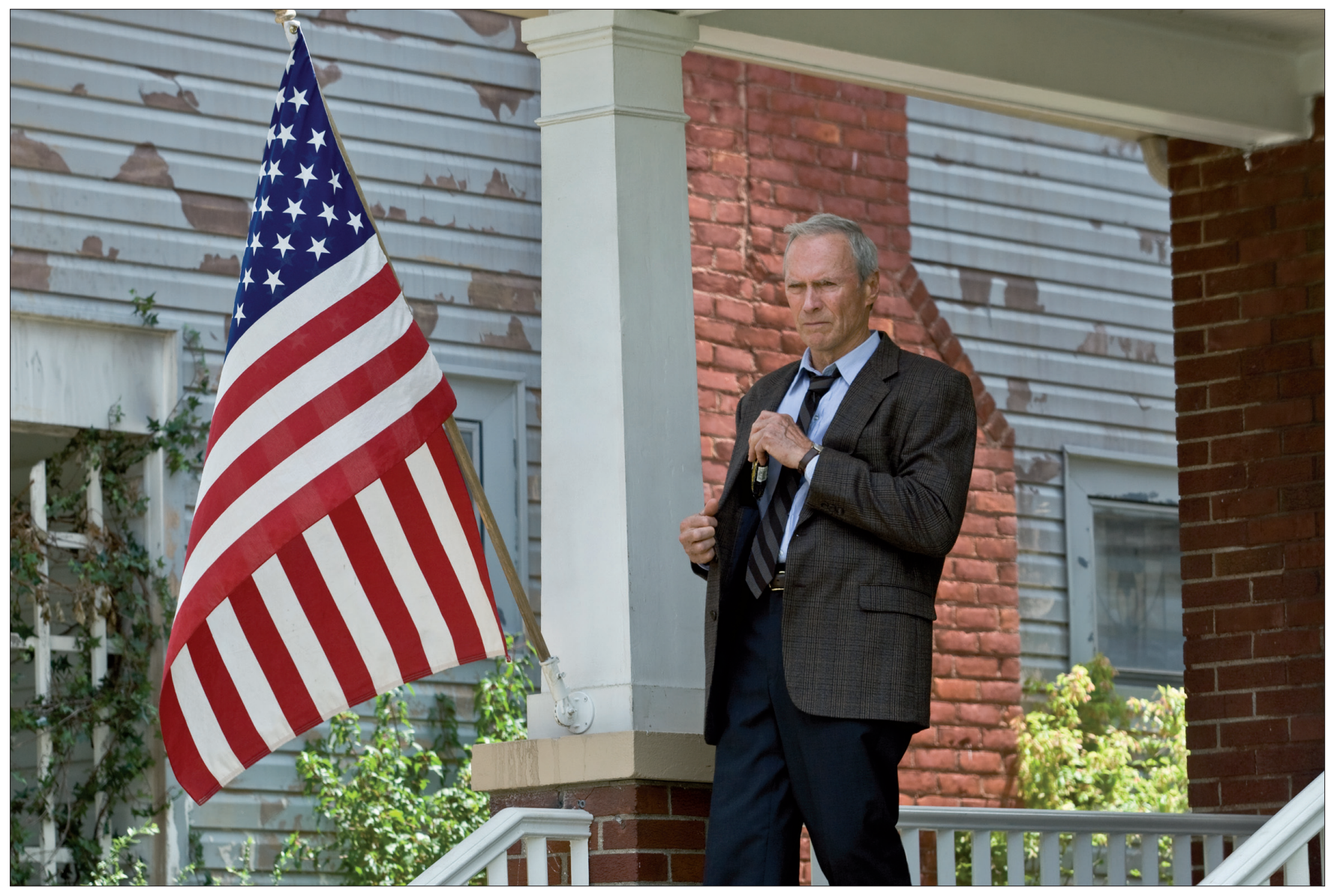

„Padesátá léta byla nejsilněǰ̌ím okamžikem Spojených států (when the things were going on) a nostalgie po nich je stále citelná: extáze moci, moc moci. Moc je zde i v létech sedmdesátých, ale kouzlo se již zlomilo. Moment orgie (válka, sex, Manson, Woodstock). Dnes orgie končí. Stejně jako všechny ostatní země rovněž Spojené státy čelí dnes měkkému rrádu světa, měkké světové situaci. Moc přišla o moc" (Baudrillard 2000, 133).

a snaží se jej přinutit, aby se po letech opět vyzpovídal, což bylo poslední přání jeho zemřelé manželky.

Kowalski poté co se sbližuje s Hmongy a začíná předávat své zkušenosti mladému Asiatovi Thaovi (kterému zprvu ř́ká posměšně Tůtů), začíná chápat, že násilí není cestou života, ale cestou smrti. Proto se $\mathrm{v}$ závěru filmu rozhodne, že kolotoč msty nebude dále roztáčet, ale naopak jej jednou provždy zastaví. Zastaví jej obětováním sebe sama ve jménu všech ostatních. Dobrovolně se stane obětním beránkem, tak jako se jím stal Ježíš Kristus, syn Boží, před dvěma tisíci lety. Walt Kowalski díky pochopení, že násilí plodí násilí, odkládá svoji zbraň (další výrazný atribut severoamerické společnosti) a volí cestu sebeobětování.

$S$ vědomím, že večer jde na smrt, naposledy zajde $k$ holiči, nechá si ušít oblek na míru a dojde se vyzpovídat. Teprve poté se vydá pomstít brutální útok hmongského gangu na Thaovu sestru Sue, která byla jeho členy zbita a znásilněna. Proti všem očekáváním, proti logice př́iběhu, proti obvyklému chodu světa i proti očekávání diváka ale Walt, zosobněný „drsným Harrym“ Clintem Eastwoodem, neodchází k členům gangu, aby je zabil, ale aby se naopak sám stal obětí jejich vraždy. Sám se dobrovolně stává obětním beránkem a jde na smrt. A pro jasné připomenutí křestan- ského motivu se jeho tělo poté, co se skácí pod deštěm kulek, nachází v pozici ukřrižovaného Krista. ${ }^{6}$

\section{WALTU゚V ODKAZ}

Závěrečný dovětek pak jen polopaticky doříkává již viděné. Poté co se opět vracíme do kostelních lavic, abychom byli svědky pohřbu Walta Kowalskiho, kterého se kromě jeho rodiny a prátel také účastní - $\mathrm{v}$ přední lavici a $\mathrm{v}$ tradičních úborech - jeho asijští prátelé, jsme svědky setkání u notáře, kde dochází $\mathrm{k}$ čtení Waltovy závěti. $\mathrm{K}$ rozhořčení jeho rodiny se otec rodu Walt rozhodl odkázat dům místní farnosti (rozhodl

6 Možnost křestanské interpretace Waltovy smrti představil v eseji Violence and Truth in Clint Eastwood's Gran Torino portugalský akademik Antonio Machuco. Ten např́klad ukazuje, že poslední Waltova slova před smrtí: „Me, I got the light,“ ztrácí svůj původní význam, jsou-li přeložena jako ,já mám oheň“, jak je tomu v českých titulcích i v českém dabingu. Tato věta totiž odkazuje na slova Ježíše Krista: „Já jsem světlo světa; kdo mě následuje, nebude chodit ve tmě, ale bude mít světlo života“ (J 8, 12), což je zásadní konotace, která se v překladu zcela ztrácí. 
se tedy poukázat na důležitost křestanských tradic) a svůj milovaný vůz Gran Torino daroval svému příteli Thaovi.

Tato scéna je pro námi zvolený způsob interpretace velice důležitá, i když jen opakuje již jednou sdělené. Zjištujeme totiž, že Walt se vlastně zř́ká své rodiny - společnosti pozdní doby, společnosti postfordistické a individualistické - a odkazuje to nejdražší, co má, členovi jiné společnosti a jiné kultury. To nejvzácnější, co Walt Thaovi odkázal, ovšem není automobil, výdobytek posledního století, hmotný artefakt ulehčující individuální život. To nejvzácnější je Waltův poslední čin, sebeobětování ve prospěch druhých. Tento čin totiž stojí u kořenů křestanské kultury a tento čin také umožnil Thaovi, aby mohl s klidem odjet na projíždku po slunečném pobřeží ve svém zděděném Gran Torinu.

$\mathrm{V}$ čem spatřujeme naději, o které jsme se zmiňovali na začátku této stati? Spatřujeme ji ve skutečnosti, že Thao, asijský přistěhovalec, od Walta s vděkem přijímá jak jeho obět tak jeho automobil. Přijímá - a svůj život od té chvíle může stavět - jak na myšlenkovém základu západní křest’anské civilizace, tak na jejích hmotných výdobytcích.

\section{PODĚKOVÁNÍ}

Fotografie z filmu Gran Torino pro tuto studii laskavě poskytl Magic Box.

\section{LITERATURA}

Améry, Jean (2008): O stárnutí: Revolta a rezignace. Praha: Prostor.

Baudrillard, Jean (2000): Amerika. Praha: Dauphin.

Bauman, Zygmunt (2004): Individualizovaná společnost. Praha: Mladá fronta

Bauman, Zygmunt (2002): Úvahy o postmoderní době. Praha: Sociologické nakladatelství.

Beck, Ulrich (2004): Riziková společnost: Na cestě k jiné moderně. Praha: Sociologické nakladatelství.

Beck, Ulrich (2007): Co je to globalizace? Omyly a odpovédi. Brno: Centrum pro studium demokracie a kultury.

Bible: Písmo svaté Starého a Nového zákona: (včetně deuterokanonických knih): český ekumenický překlad (2005): Praha: Česká biblická společnost.

Buchanan, Patrik J. (2004): Smrt Západu: Jak vymírání obyvatel a invaze přistěhovalců ohrožují naši zemi a civilizaci. Praha: Mladá fronta.

Casetti, Francesco (2008): Eye of the Century: Film, Experience, Modernity. New York: Columbia University Press.

Casetti, Francesco: The filmic Experience: An Introduction [online]. [cit. 200905-19]. Dostupný z WWW: www.francescocasetti.net/saggi/FilmicExperience.pdf.
Ford, Henry (1930): Moje filosofie průmyslu. Praha: Ústřední dělnické knihkupectví a nakladatelství.

Jirsa, Lukáš (2010): Sociologická imaginace a film v kulturologické perspektivě. Disertační práce. Praha: Katedra teorie kultury (kulturologie) Filozofické fakulty Univerzity Karlovy.

King, Alexandr - Schneider Bertrand (1991): První globální revoluce: Svět na prahu nového tisíciletí. Bratislava: Bradlo.

Machuco, Antonio (2009): Violence and Truth in Clint Eastwod's Gran Torino [online]. [cit. 2011-08-08]. Dostupný z WWW: http://www.anthropoetics.ucla.edu/ap1602/1602machuco.htm.

Mills, Charles Wright (2002): Sociologická imaginace. Praha: Sociologické nakladatelství.

Mokrejš, Antonín (1995): Filosofie a život - život a umění. Praha: Filosofia.

Mokrejš, Antonín (2002): Umění: A k čemu? Praha: Triton.

Morin, Edgar (2000): Les sept savoirs nécessaires à léducation du futur. Paris: Seuil.

Palouš, Radim (1991): Cas výchovy. Praha: Státní pedagogické nakladatelství.

Palouš, Radim (2000): Světověk a časování. Praha: Vyšehrad.

Patočka, Jan (1990): Kacírské eseje o filosofii dějin. Praha: Academia.

Petrusek, Miloslav (2007): Společnosti pozdní doby. Praha: Sociologické nakladatelství.

Pieper, Josef (2007): Co znamená filozofovat? Kostelní Vydří: Karmelitánské nakladatelství.

Postman, Neil (2010): Ubavit se k smrti: Veřejná komunikace ve věku zábavy. Praha: Mladá fronta.

Tomeš, Jaroslav (2008): Naše nynější modernita: Diskuse o dějinné perspektivě modernity v pojetí Jaroslava Krejčího. Praha: Sociologické nakladatelství.

Wallerstein, Immanuel (1999): The End of the World as We Know It: Social Science for the Twenty-first Century. Minneapolis - London: University of Minnesota Press.

Jirsa, Lukáš (1. 10. 1981, Praha), filmový kritik a kulturolog; absolvent Katedry teorie kultury (kulturologie) a Ústavu románských studií Filozofické fakulty Univerzity Karlovy v Praze. Ve své disertační práci Sociologická imaginace a film v kulturologické perspektivě se zabýval možností interpretace filmu jakožto prostředku poznávání současného světa. O filmu a společnosti přednáší na Filozofické fakultě Univerzity Karlovy v Praze a na Vyšší odborné škole publicistiky. Spolupracuje s neziskovou televizí Noe, působí jako odborný poradce Mezinárodního filmového festivalu Karlovy Vary, je editorem čtvrtletníku Universum (revue České křestanské akademie). O filmu píše do Katolického týdeníku, čtvrtletníku Universum a odborné revue Film a doba. Na mezinárodních filmových festivalech zasedá v ekumenických porotách a $\mathrm{v}$ porotách FIPRESCI (The International Federation of Film Critics).

Kontakt: Mgr. Lukáš Jirsa, Ph.D., e-mail: lukas.jirsa@seznam.cz. 